\title{
PERCURSO SEMÂNTICO DO ASSÉDIO MORAL NA TRAJETÓRIA PROFISSIONAL DE MULHERES GERENTES
}

\section{RESUMO}

O artigo tem o objetivo de evidenciar comportamentos de assédio moral na trajetória profissional de 12 mulheres gerentes de empresas privadas de Minas Gerais que se consideravam assediadas, relacionandoos às categorias de Hirigoyen (2002a e 2002b). A coleta dos dados foi realizada por meio de histórias de vida com investigação participativa e os dados foram interpretados por meio da análise de discurso. Essa estratégia metodológica possibilitou observar que as relações de poder que permeiam o ambiente organizacional trazem uma possibilidade de (re)leitura antiga do que se denomina hoje assédio moral. Grande parte das entrevistadas continua sofrendo assédios, sendo talvez até mais expostas ao fenômeno por estarem em um terreno de domínio masculino, o que pode remeter aos fatores culturais brasileiros.

\section{Alessandra Morgado Horta Corrêa UFMG}

\section{Alexandre de Pádua Carrieri UFMG}

\begin{abstract}
This research has the objective of pointing out to moral harassment behavior during the professional trajectory of twelve women managers working for companies in the Brazilian state of Minas Gerais, who declared themselves harassed. Answers were related to the categories of Hirigoyen $(2002 a, 2002 b)$. In order to achieve the purpose of the research data were collected through life histories with participative investigation technique and analyzed by the discourse analysis methodology. This methodological strategy permitted to observe that power relations present in the working environment bring possibilities of an old reading of what is named today moral harassment, and most of the women managers still suffer moral harassment, probably more exposed, as they work in an masculine dominated environment that can be explained by brazilian cultural factors.
\end{abstract}

PALAVRAS-CHAVE Assédio moral, mulher gerente, relações de poder, histórias de vida, análise do discurso.

KEYWORDS Moral harassment, woman manager, power relations, life histories, discourse analysis. 


\section{INTRODUÇÃO}

O processo moderno de gestão, no qual o desemprego e a exclusão social são comuns, favorece um ambiente organizacional de autoritarismo e competitividade com práticas de gestão pouco claras, gerando nos trabalhadores estresse e insegurança. A empresa, em um processo econômico competitivo, pode fragilizar os indivíduos para atingir os próprios objetivos, sendo complacente com certos abusos de poder. Assim, transforma-se em um ambiente ideal para o crescimento de formas de assédio moral, um fenômeno degradador das relações de trabalho. No Brasil, por conservar fortes características patriarcais, e à medida que vem aumentando a representatividade das mulheres nas empresas, em diversas funções e níveis hierárquicos, o assédio moral pode se tornar crítico, já que está geralmente correlacionado às disputas de poder e competitividade.

Dessa forma, diante da crescente presença feminina no trabalho e da persistência das desigualdades, e buscando contribuir para os estudos administrativos, objetiva-se com o artigo evidenciar formas de assédio moral sofridas por 12 mulheres gerentes de empresas privadas de Minas Gerais que se consideravam assediadas. A pesquisa foi baseada em histórias de vida, o que permitiu levantar a trajetória profissional, e a sistematização e o prolongamento do fenômeno.

Tal corte, com variáveis ainda não aprofundadas em pesquisas empíricas - mulher assediada e gerência -, fundamenta-se em literatura especializada (Barreto, 2000, 2002; Hirigoyen, 2002b), na qual se verifica que as mulheres têm liderado as estatísticas de assédio moral, e que em hierarquias superiores o fenômeno tende a ser mais sutil.

\section{PROCESSO DE ASSÉDIO MORAL NAS ORGANIZAÇÕES}

$\mathrm{Na}$ literatura, encontram-se vários conceitos de assédio moral, porém é um desafio descrever e conceituar o fenômeno, já que os autores citam diversas formas de retratar as atitudes do agressor. Dessa maneira, com base na revisão bibliográfica realizada (por exemplo, Aguiar, 2003; Barreto, 2000, 2002; Freitas, 2001; Hirigoyen, 2002a, 2002b; Leymann, 1996), neste artigo, o assédio moral nas organizações foi entendido como: condutas hostis, impróprias, repetitivas e prolongadas por meio de comportamentos, palavras, gestos e/ou situações humilhantes com o indivíduo ou um grupo, durante a jornada de trabalho. O assédio moral é mais comum em ocasiões de uso do poder e visa atingir a auto-estima, segurança ou imagem do indivíduo, fazendo-o duvidar de si e de sua competência. Tais abusos podem ocasionar danos à sua personalidade, dignidade, ou integridade física ou psíquica, desestabilizando-o perante os colegas e a organização, e colocando em risco seu próprio emprego e sua ascensão profissional. Heloani (2004) pontua que a perversidade do assediador, destacadamente a frieza e racionalidade, alia-se às práticas organizacionais e corrói os valores éticos essenciais. Assim, não é raro que os agressores sejam admirados pela eficiência e eficácia do próprio trabalho às custas da arrogância e do menosprezo dispensados aos subordinados. A vítima, segundo Ramírez (2002), pode ser escolhida por possuir determinadas características pessoais, que incomodam o agressor, que vão desde dinheiro até habilidades e desempenho.

$\mathrm{Na}$ tentativa de caracterizar o processo de assédio, Hirigoyen (2002a) informa que ele tem como origem um ato inofensivo, quase imperceptível. Primeiramente, a vítima prefere levar na brincadeira e não se mostrar ofendida, e quando as práticas se tornam sistemáticas e repetitivas, passa a se sentir acuada, humilhada e inferiorizada. Ao longo do assédio, a pessoa sente fobia ao ver o agressor, desencadeando-se o medo, e, caso reaja, o agressor pode utilizar uma manobra para confundir a vítima e fazer com que cometa erros, justificando então a agressão ao grupo ou mesmo à própria vítima. Tenta-se, com o processo de assédio, estigmatizar a vítima, dizendo para o grupo que a pessoa é de difícil convivência, tem personalidade forte ou é louca, e, nesse momento, o perverso pode legitimar o processo perante o grupo, que passa também a ter comportamentos diferentes com a vítima. Essa fase de hostilidade declarada pode levar a uma destruição psíquica ou até mesmo ao suicídio.

Buscando um entendimento, Hirigoyen (2002a, 2002b) correlaciona as seguintes formas de assédio com as causas: 1) assédio horizontal - colega é agredido por colega(s) -, quando grupos não toleram diferenças (mulher em um grupo de homens, homem em grupo de mulheres, homossexualidade, diferença racial, religiosa ou social) ou há disputa de um cargo; 2) assédio ascendente - superior é agredido por um ou vários subordinados -, sendo esse o mais raro, caracteriza-se quando o estilo de administrar é reprovado ou não é aceito pelo grupo; 3) assédio descendente - subordinado(s) é(são) agredido(s) pelo superior, sendo mais comum o tratamento tirânico em relação ao o(s) subordinado(s) com objetivo de eliminação, valorização do poder em si ou pedido de demissão para contornar os procedimentos legais de dispensa. Um fator agravante 
do assédio moral descendente é que algumas empresas têm como política deixar o chefe agir com os subordinados de maneira perversa, sem intervir. Já o assédio ascendente, segundo Ramírez (2002), pode ocasionar a demissão do subordinado, mas, por outro lado, há casos em que um grupo de empregados demonstra uma posição de força contra um chefe. Ao pesquisar 193 pessoas que se consideravam assediadas na França, Hirigoyen (2002b) indicou que $58 \%$ dos casos relatados tinham vindo da hierarquia, $29 \%$ de pessoas diversas, inclusive chefes e colegas, $12 \%$ de colegas e $1 \%$ de um subordinado.

Revisando a classificação de comportamentos de assédio moral, Hirigoyen (2002b) identifica quatro categorias: 1) deterioração proposital das condições de trabalho; 2) isolamento e recusa de comunicação; 3) atentado contra a dignidade; 4) violência verbal, física ou sexual. Segundo a autora, os comportamentos contra o trabalhador na produção ocorrem de forma direta (verbal e física). Em hierarquias superiores, as agressões tornam-se mais sutis, difíceis de caracterizar e, geralmente, percebidas somente pela vítima. Esses aspectos podem ser explicados, já que na produção as atividades são mais definidas e o indivíduo consegue verificar se a tarefa foi executada corretamente, ao passo que na área administrativa existem ambigüidades, as tarefas são flexíveis e muitas vezes subjetivas.

No Brasil, Barreto (2000) tem liderado pesquisas de assédio moral. Embora a autora não tenha utilizado o termo assédio moral, retratou as humilhações sofridas pelos trabalhadores na triangulação saúde, doença e trabalho. Em seu outro artigo, Barreto (2002) define as humilhações, os constrangimentos e as situações vexatórias no trabalho como assédio moral, que pode ser adotado como uma política da empresa, sendo os atos executados por representantes legais da organização para que alguns trabalhadores peçam demissão.

Dados levantados em pesquisas sobre assédio moral indicam que as mulheres pertencem ao grupo mais assediado. Barreto (2000, p. 212) informou, em sua pesquisa, que "[...] as mulheres vivenciaram um número maior de situações em que foram mais humilhadas do que os homens". Isso tende a ocorrer quando as mulheres atingem categorias tradicionalmente reservadas aos homens. Aí, passam a ser objeto de brincadeiras grosseiras e têm seu trabalho desconsiderado.

Costa (1995) considera que o assédio moral, inclusive o de tipo sexual, é um reflexo da cultura da sociedade, pois os fatores históricos, sociais, econômicos e culturais de uma sociedade influenciam a visão dos indivíduos em relação ao sexo, trabalho e papel social. Os dados apresentados na pesquisa podem estar relacionados às signi- ficações culturais brasileiras provindas do regime escravocrata, demarcando uma sociedade autoritária e hierarquizada, com ênfase na relação dominante-dominado. A mulher é muitas vezes vítima de domínio ou de abuso do parceiro, reprimida sexual e socialmente, e menos acostumada a processos competitivos e relações de poder. Já o homem é visto como menos sensível e intuitivo (Aguiar, 2003; Costa, 1995).

Alguns autores (como Davel e Vasconcelos, 1997; Freitas, 2001) ressaltam que a mulher na organização continua desempenhando funções de subordinação a chefias, predominantemente masculinas, pois as organizações refletem a sociedade patriarcal, onde a mulher sofreu e ainda sofre influências do poder masculino. Além de receber salários menores do que os dos homens, e ter dificuldade de ascensão na hierarquia, a mulher tem-se deparado com o poder, a resistência ou mesmo a indiferença masculina. A organização, como um ambiente de constantes interações sociais, é palco de disputas de poder. Na esfera de relações culturais e de poder, muitas organizações tendem a desenvolver práticas de centralização de domínio e de autoritarismo que podem recair em assédio moral.

\section{PROCEDIMENTOS METODOLÓGICOS}

A pesquisa é qualitativa e descritiva, tendo como sujeitos de análise 12 mulheres em cargos de gerência há pelo menos um ano em empresas privadas em Minas Gerais, com trajetórias profissionais superiores a cinco anos, e que se declararam assediadas durante a entrevista preliminar. Nessa etapa, optou-se por não usar o termo assédio moral, e sim o conceito para a seleção dos sujeitos, já que os indivíduos tendem a confundi-lo com o assédio do tipo sexual, o que poderia causar inibição nas entrevistadas e/ ou um viés à pesquisa. Após 15 entrevistas preliminares, completou-se a seleção de 12 gerentes assediadas, que aceitaram participar da pesquisa desde que não fossem identificadas.

Para investigar o assédio moral em organizações, recorreu-se às histórias de vida, que permitem a "construção de um objeto científico cujo fundamento é um conjunto real e histórico de relações sociológicas e empíricas vividas por um grupo" (Marre, 1991, p. 110). As histórias de vida foram coletadas por meio de investigação participativa, o que pode levar à plena expressão da experiência do indivíduo (Marre, 1991). Assim, solicitou-se à gerente que narrasse a sua trajetória profissional, possibilitando-se a reconstrução de experiências profissionais e comportamentos de assédio moral. 
Foi escolhida a análise de discurso como método para a leitura das histórias de vida. Segundo Fiorin (2003, p. 11), "o discurso são as combinações de elementos lingüísticos (frases ou conjuntos constituídos de muitas frases) usadas pelos falantes com o propósito de exprimir seus pensamentos, de falar do mundo exterior ou de seu mundo interior, de agir sobre o mundo". Na dimensão intradiscursiva, o percurso semântico é a principal categoria descritiva, veiculando a visão de mundo defendida, e se organiza, implícita ou explicitamente, por meio de temas e figuras. Enquanto as figuras utilizam elementos do mundo natural, como mulher e empresa, os temas englobam elementos não presentes no mundo real, como alegria (Faria, 2001; Fiorin, 2003).

Nesta pesquisa, levantou-se o percurso semântico do assédio moral e subconjuntos no seu interior, para detalhar mais os níveis da análise, e as estratégias de persuasão discursivas, como recursos da linguagem relevantes para a construção dos sentidos. As estratégias de persuasão utilizadas são descritas a seguir, com base nos autores Faria e Linhares (1993), Maingueneau (1998) e Rodrigues (2004): seleção lexical - a escolha do vocabulário usado no discurso não deve ser percebida como aleatória, pois é um relevante recurso argumentativo, delimitando a perspectiva adotada pelo narrador; construção de personagens discursivas - as personagens não são criadas casualmente, encenam conflitos e dão legitimidade e credibilidade às narrativas; silenciamento - alguns temas podem ser silenciados no discurso, desviando a atenção do interlocutor; relação entre explícitos e implícitos - os implícitos não constituem o objeto nítido da enunciação, já que, por algum motivo, o narrador não desejou ou não pôde explicitá-los, mas eles aparecem a partir dos conteúdos explícitos. $\mathrm{Na}$ análise dos dados, foram identificados os pressupostos implícitos, partes integrantes do enunciado, e os subentendidos, que são inferências retiradas do contexto pelo interlocutor, com a ajuda de um raciocínio.

\section{PERCURSO SEMÂNTICO DO ASSÉDIO MORAL}

Nesse percurso semântico, os comportamentos de assédio moral observados durante os discursos de 12 mulheres gerentes foram agrupados em três subconjuntos, e relacionado às categorias de Hirigoyen (2002b):

- assédio moral descendente, com os seguintes temas: rejeição, relação de afinidade, assédio do tipo sexual, preconceitos contra a mulher, ameaça ao poder;

- assédio moral ascendente, com o tema único: rejeição;
- assédio moral horizontal, com os temas: rejeição, competência e ameaça ao poder.

\section{Subconjunto do assédio moral descendente}

No discurso de G1, foi identificado o tema rejeição, segundo o trecho (01): "o presidente me ignora... conversa com os outros gerentes das outras unidades... sou um zero à esquerda". O assédio ocorre desde que assumiu a gerência regional financeira, há dois anos e seis meses, e pode ser classificado por Hirigoyen (2002b) como isolamento e recusa de comunicação. O assédio apareceu no vocábulo "ignora" e na expressão metafórica "zero à esquerda", em que pode estar subentendida a rejeição à Gl no cargo gerencial pelo presidente.

O tema relação de afinidade foi relatado por G2 e ocorreu na empresa em que trabalhou por seis anos, onde era assessora do superintendente, que a demitiu em razão do ciúme da esposa devido à proximidade dos dois. No trecho (02): "'[minha esposa] não admite mais você trabalhando aqui'... eu saí, ele não comunicou... a situação deu força à fofoca", os vocábulos "não comunicou" indicam a atitude do superintendente de silenciar sobre o motivo da saída de G2 aos colegas, o que ocasionou a "fofoca" de que eles estavam tendo um caso, que leva à categoria atentado contra a dignidade, em razão dos rumores depreciativos gerados.

G5 identificou esse mesmo tema no assédio moral que vem sofrendo na empresa atual, desde que assumiu, há dois anos e seis meses, a gerência de Marketing, relacionado ao diretor, que a critica de forma exagerada perante colegas e superiores. Conforme declara, isso é demonstrado por "várias vezes" em reuniões, quando o diretor discorda de algum item apresentado por G5 e passa a atacá-la "como todos os outros". Esse comportamento fica retratado no fragmento (03): "[...] me sinto usada... não recebo suporte suficiente... ele nem sequer olha... se tem alguma coisa que ele discorda, ao invés dele me proteger... ele me bate como todos os outros estão batendo... várias vezes... uma forma de te desqualificar", que indica a categoria de assédio deterioração proposital das condições de trabalho. Já no fragmento (04): "[...] ele falou para a equipe inteira que eu nunca transferi para ele os problemas da área... ele se defendeu e me colocou no fogo... ele me desautoriza... ele vai diretamente à pessoa, pára o que a pessoa estava fazendo e manda ela fazer outra coisa", subentende-se que o mesmo diretor interfere na gestão da gerente, causando tumultos e conflitos entre G5 e os subordinados. Essas outras formas de assédio do diretor remetem à categorização atentado contra a dignidade.

O terceiro tema, assédio do tipo sexual, engloba os casos 
categorizados pelo mesmo nome por Hirigoyen (2002b). $\mathrm{O}$ assédio sexual foi reconhecido como uma forma de assédio moral, nas abordagens de Freitas (2001), Hirigoyen (2002a; 2002b) e Ramírez (2002), pois ambos se relacionam com autoridade e poder. Entendeu-se como assédio sexual uma forma de violência psicológica, como propostas de sexo, insinuações sexuais, comentários jocosos, exibição de material pornográfico, exigência de troca de favores sexuais por vantagens, podendo ir desde uma observação verbal constrangedora até uma agressão física.

G3 relatou duas situações de assédio descendente do tipo sexual, que ocorreram na empresa anterior, na qual trabalhou por 18 anos. Os casos foram considerados por G3 como assédio do tipo sexual e relacionados às personagens "todos dois", segundo o trecho (05): "[...] todos dois que me assediaram eram muito poderosos", remetendo ao gerente de Informática e ao de Produção. O assédio do gerente de Informática pode ser considerado como do tipo sexual, uma vez que foi caracterizada a relação de poder e foram utilizadas formas típicas desse tipo de assédio, como comentários considerados inconvenientes. Foram cantadas e olhares maliciosos, que constrangeram G3 em seu local de trabalho, conforme ela assinalou com a seleção lexical "super sem graça" e "contornar" (06). No entanto, após "seis meses" (06) de assédio, G3 "cedeu", ou seja, o assediador passou a ser correspondido, fato de que ela se culpou por meio dos vocábulos "fragilizada" e "falta de maturidade".

(06) [...] ele realmente me assediou... a gente estava em reunião e ele não tirava os olhos de mim e eu ficava $\underline{\mathrm{su}-}$ per sem graça... muito difícil em um determinado momento para eu contornar... ele deve ter ficado seis meses me abordando para depois eu ceder... não sei se eu tava fragilizada, falta de maturidade.

O segundo caso ocorreu com o gerente de Produção e durou um ano e meio. G3 recordou que, naquele momento, já detinha poder na organização, relacionando o poder com a ocupação do cargo de consultora interna. Também se percebem no relato algumas formas de assédio, como as citadas no caso anterior, além de abordagem física, como toques indesejáveis em partes do corpo, e ataque físico, que são indicados na seleção lexical do trecho (07): "[...] tentava me beijar a força... tentava me agarrar... chegava, me abraçava e eu ficava brigando com ele e tal e assim... eu ficava muito incomodada, eu xingava e tal, mas chegou num momento que eu cedi também".

No trecho (08), G3 assinala que esse assédio evoluiu para um jogo de ganhos dos dois lados, pois explicitou que teve "ganhos" e que também "usou" o assediador. Nos trechos "eu percebi que na verdade ele estava me usando também" e "usava mais", está implícito, pressuposto que, até um certo momento, G3 pensava que o gerente de Produção não tirava vantagem da relação. Percebeu depois que, na verdade, ela era a mais usada, nisso fica subentendida a sutileza do assediador. Já com a mobilização da personagem "as pessoas", G3 deixou subentendido que não foi a única usada por esse gerente, porém silenciou sobre quem teriam sido as outras pessoas.

(08) Eu acabei cedendo e mesmo porque a questão dos ganhos que você começa a ter indiretos... você começa a ter mais abertura... começa a perceber que a pessoa facilita as coisas para você no trabalho... ele usava as pessoas e hoje eu acho que ele me usou muito, depois de um tempo eu percebi que na verdade ele estava me usando também. Da mesma forma que eu entrei no jogo e usei, lógico, mas ele me usava mais para conseguir as coisas porque ele sabia que eu tinha penetração muito grande junto à diretoria.

G6 relatou esse tipo de assédio sofrido por um ano na empresa em que trabalhou por cinco anos, quando era assistente de auditoria e única mulher profissional, com a mobilização da personagem gerente responsável. O que parece ter tornado a situação difícil para G6 foi o fato de que, em um ambiente totalmente masculino, e somente ela de mulher profissional, optou por não denunciar o assédio, para não sofrer preconceito, conforme subentendido no trecho (09): "se eu reclamasse... eu tinha medo de sofrer as conseqüências, ou seja, mulher, já é a primeira mulher que entra aqui e já está dando problema... era melhor eu ficar calada porque senão eu podia sofrer uma retaliação".

Além das investidas, G6 recordou-se das avaliações realizadas pelo gerente responsável, que eram "muito boas, inclusive muito melhores", o que lhe causou mais constrangimentos com os colegas homens, que passaram a não confiar na performance de G6. Ficou subentendido que, com as boas avaliações, os colegas começaram a acreditar que o assédio estava sendo correspondido, o que colocou em risco a imagem de G6 na empresa e atentou contra a sua dignidade, com insinuações desdenhosas para qualificá-la. No entanto, ficou silenciado se realmente essas avaliações recebidas foram justas.

Já G12 relatou um caso de assédio do tipo sexual quando era gerente em um banco, onde trabalhou por 16 anos, com a mobilização da personagem diretor. $\mathrm{O}$ assédio ficou indicado nas expressões "gosto muito de você", "não vou 
te demitir" e "ia lá na minha casa" (10). Nos vocábulos "perseguir", "fazer mais" e "cobrar" (10), G12 deixa implícita, subentendida, a intimidação por não ter aceitado as investidas sexuais do diretor.

(10) [...] um diretor... me chamou lá na diretoria e falou assim: "[G12], amanhã eu vou estar demitindo, mas eu gosto muito de você e não vou te demitir". Aí este homem começou a me perseguir... ia lá na minha casa. E dizendo assim: "Olha, eu que deixei você aqui, agora você tem que fazer mais. Olha, a sua produção está pouca”. Cobrar pelo que ele tinha feito por mim.

G7, coordenadora de compras há quatro anos, indicou o tema preconceitos contra a mulher em seu discurso, ao relatar o salário inferior pago às mulheres gerentes pela personagem diretor. No trecho (11): “[...] a questão salarial... é bem mais baixo do que os homens... eu já ouvi várias vezes em reunião aqui [o diretor dizendo]: 'se você não está satisfeita'... é o medo de perder o emprego", está implícita, subentendida, a intimidação. Tal assédio pode ser considerado como uma forma de desqualificação, conforme a primeira classificação proposta por Hirigoyen (2002a).

G10 relatou um assédio no cargo de supervisora de RH, que ocupa até hoje, proveniente do dono, que foi categorizado como deterioração proposital das condições de trabalho e isolamento e recusa de comunicação. No trecho (12), G10 deixou implícito, subentendido, o período turbulento pelo qual passou desde que entrou na empresa, há 12 anos, com a passagem de 13 gerentes de RH, contratados pelo dono da empresa. Na metáfora "saía de cena" e na metonímia "sem escutar a voz", G10 subentendeu que deixava de ser procurada pelo dono a cada entrada de um novo gerente de RH, e essa situação era revertida quando o dono a procurava novamente.

(12) [...] nenhum completou um ano... passaram por aqui 13 gerentes de Recursos Humanos... eu saía de cena... ficava de um mês a seis meses sem escutar a voz do [dono]... depois, quando o [dono] começava a se aproximar de mim de novo... eu ficava sempre numa situação difícil porque fazer uma coisa que o gerente estava ali para fazer... isso foi sofrido $[. .$.$] .$

No trecho (13) "[...] diretor... nunca respeitou mulher como gente, como profissional... eu queria me posicionar de alguma coisa, ele desdenhava... na frente dos meus subordinados... contra tudo aquilo que eu falava. Palavrão, palavrão, palavrão", G12 descreveu um caso ocorrido no cargo de gerente geral de um banco no qual trabalhou por três anos, proveniente da personagem diretor. A gerente indicou o assédio nas marcas lingüísticas sublinhadas, que foi categorizado como atentado contra a dignidade, já que o assediador desacreditava G12 e a injuriava com termos degradantes.

No último tema deste subconjunto, ameaça ao poder, G3 lembrou ter tido problemas com a diretora durante um ano e seis meses, quando era assessora de RH, conforme o fragmento (14): "[...] diretora... não me chamava para determinadas reuniões, tomava algumas decisões da minha área e depois apenas me comunicava... ela acabava dificultando alguns trabalhos que eu propunha e não conseguia implementar". Os problemas relatados caracterizam o assédio por deterioração proposital das condições de trabalho e isolamento e recusa de comunicação.

Depois, G3 foi trabalhar com o diretor industrial como gerente de RH, quando teria ocorrido outro assédio, relatado no trecho (15). G3 ressaltou a existência de conflitos de poder entre as personagens diretor e diretora e indicou que o convite de trabalho teve como objetivo "atacar" a diretora. Por meio da marca lingüística "usada", G3 deixou subentendida a manipulação do diretor e discorreu sobre um incidente entre ele e a diretora, em que se considerou usada, e a diretora se sentiu ameaçada por G3, o que resultou no pedido de demissão por G3. Esse caso de assédio foi entendido como deterioração proposital das condições de trabalho, uma vez que G3 foi induzida ao erro pelo diretor.

(15) [...] diretor industrial... eles estavam brigando muito, tinha muita briga de poder... eu fui usada... o objetivo dele era atacar a [diretora]. Ele me pediu que eu sondasse a [psicóloga] para trabalhar comigo, sem falar com a [diretora]. [A diretora] aprontou um escândalo com o diretor, falando que nós estávamos tirando profissionais da diretoria dela sem comunicar a ela... ele não me apoiou, sabe? Ele não me apoiou... falei com ele: "Não fico".

G5 mencionou um caso de assédio na empresa anterior, que durou um ano e seis meses, período em que ficou no cargo de analista de $\mathrm{RH}$, subordinada à personagem chefe, que remete ao gerente. No trecho (16): "um chefe... eu tinha um potencial... tinha as minhas idéias, ele não deixava eu aparecer... barrava, não deixava, não passava. Não dava importância... não discutia. A mesma coisa que você estar falando com uma porta”, verifica-se o assédio por isolamento e recusa de comunicação.

Já G6 relatou um caso com a gerente financeira da empresa na qual ficou por apenas seis meses no cargo 
de supervisora financeira. No fragmento (17), a gerente cita vários comportamentos que podem ser classificados como deterioração proposital das condições do trabalho e isolamento e recusa de comunicação.

(17) Ela era muito cheia de artimanhas... melindres, muito grosseira, ela não passava as coisas... me impunha muito as coisas da maneira dela e eu não estava tendo liberdade... tentava realmente me rebaixar... me barrando... ela me privava de diálogo direto com o diretor... sempre pegava [meu trabalho]... refazia tudo com a letra dela, refazia para poder passar... me travava hierarquicamente.

No caso de G9, o assédio ocorreu na empresa atual, quando era analista financeira, e foi proveniente da personagem supervisora. As vítimas do assédio foram "uma equipe inteira" (18), o que incluiu G9. O processo teve duração de oito meses, período em que a supervisora ficou na empresa. G9 ressaltou as atitudes adotadas pela assediadora no fragmento (18), que levam às categorias atentado contra a dignidade, deterioração proposital das condições de trabalho e isolamento e recusa de comunicação.

(18) Era uma equipe inteira... durante reuniões ela falava de forma debochada... um olhar meio dissimulado... na nossa frente era uma coisa e na frente da nossa gerente era outra... muito agressiva... ela se apropriava de idéias...

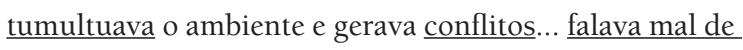
mim e de [outra colegal para a [gerentel... não me inspirava confiança... gerava um certo desconforto.

G10 citou dois casos de assédio descendente no cargo de supervisora de RH provenientes das personagens gerentes de RH, nomeadas GRH1 e GRH2. O relacionado à GRH1 durou um ano e ficou indicado nos vocábulos sublinhados do fragmento (19), levando à categoria atentado contra a dignidade, destacando o indivíduo que é injuriado com termos degradantes. G10 também deixa subentendido o movimento que passou a ser feito por GRHl para que G10 não assumisse o cargo gerencial, indicando gerentes para a área de RH, o que pode ser considerado como assédio, comportamento incluído na categoria deterioração proposital das condições de trabalho.

(19) Acho que foi o período que eu mais escutei palavrão... do tipo assim: "Ô loira gostosa!"... aquela gritaria... "[palavrão]! Deu problema nessa [palavrão] dessas férias de novo eu enfio o [palavrãol". Eu acho que até esse tanto de gerente que teve depois era incentivado por ele... aquela história: "Eu não fiquei lá mas ela não vai ser ge- rente, alguém vai ser e vai ser homem"... ele influenciava muito o [dono].

$\mathrm{O}$ assédio moral proveniente de GRH2, indicado por GRH1, foi incluído na categoria violência verbal, o que fica indicado na seleção lexical do fragmento (20): “[...] [GRH2], indicado pelo [GRH1]... extremamente estúpido... grosseiro, estúpido... chegou me atacando... [GRH1] deve ter falado: 'Ah, eu já tentei, o pessoal faz amizade e fica bonzinho com ela... vai ter que chegar dando tapa'... comigo era declarado".

Para G11, o assédio de que tem sido vítima há dois anos e meio no cargo de gerente de Planejamento é proveniente do presidente, segundo o trecho (21). Esse assédio foi enquadrado na categoria deterioração proposital das condições de trabalho, pois Gll foi cerceada em sua autonomia no trabalho e retirada de atividades que normalmente lhe competiam.

(21) [...] o [representante do acionista] começou a mandar recados para o presidente por mim... [o presidente] ficou possesso pelo cara ter me escolhido... eram informações seríssimas que mexiam demais com ele... um poder imenso!... ele tem a certeza que ele não me domina... ninguém questionava as minhas viagens. Então hoje para eu fazer uma viagem tem que ser aprovada pelo presidente... agora ele tem domínio... chegou um ponto que eu não tinha mais a flexibilidade que eu tinha para fazer o planejamento nas empresas... começa a te cortar... coisas que você fazia antes as pessoas passam a fazer... e isso é um recado muito grande dentro de uma organização, quem você prestigia... as minhas atividades permaneceram as mesmas, o meu grau de mobilidade é que foi cortado.

Dos temas tratados neste subconjunto, o de maior freqüência foi ameaça ao poder, e tiveram um ponto em comum: de alguma forma, a gerente ameaçava o poder do superior hierárquico.

\section{Subconjunto do assédio moral ascendente}

$\mathrm{O}$ segundo subconjunto desse percurso semântico teve como tema único rejeição, referindo-se à rejeição da gerente no cargo por um ou vários subordinados. Um desses casos foi relatado por Gl e ocorre desde que assumiu a gerência regional financeira, há dois anos e seis meses. No trecho (22) "[...] ele não passou a ser o chefe.... todo mundo vai e resolve as coisas comigo e ele fica lá no cantinho dele, resolve... não compartilha comigo. Ele não vem na $\underline{\text { minha sala... eu tenho que procurá-lo... toma as decisões }}$ e passa por cima de você", Gl caracterizou o contador, 
seu subordinado, que, segundo ela, gostaria de estar no seu lugar. O contador tem como comportamento de assédio isolamento e recusa de comunicação, pois recusa o contato e não dialoga com G1, o que deixa subentendida a demarcação de um jogo de poder.

Para G2, o assédio ascendente do qual diz ser vítima no cargo de gerente comercial há um ano tem como personagem antiga amiga pessoal, agora sua subordinada. $\mathrm{O}$ assédio, categorizado como deterioração proposital das condições de trabalho, foi relatado nas expressões sublinhadas no trecho (23), atitudes que são realizadas de forma não profissional e perante outros colegas: "[...] não me aceitou como chefe... ela não tem o respeito... ela deturpava a situação para que eu ficasse a errada na história... retruca de uma forma que não é profissional... faz na frente de todo mundo".

No trecho (24) "[...] eu passei a ter problemas com ela porque ela não me aceitava, ela competia muito comigo... ela me questionava muito [...]", G3 relacionou um caso de assédio ascendente na empresa anterior, quando assumiu a gerência de RH e a personagem ela passou a ser sua subordinada, que foi categorizado por deterioração proposital das condições de trabalho.

G4 mobilizou a personagem secretária no fragmento (25), para citar o assédio de que parece ser ainda vítima há 10 anos, desde que está como gerente de RH. O assédio foi relatado nos trechos sublinhados e remete às categorias deterioração proposital das condições de trabalho e atentado contra a dignidade, uma vez que G4 é desacreditada no trabalho pela secretária que espalha rumores a seu respeito.

(25) [...] secretária... era muita fofoca, ela falava mal de

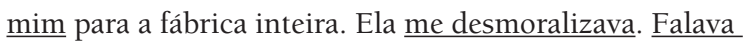
mal do meu trabalho, a forma como eu conduzia... [Entrevistadora: "[...] fazia ou faz, alguma coisa para te prejudicar?"] Sempre fez, sempre. Semana passada mesmo eu fui conferir um serviço que ela está cansada de fazer e eu vi que aquilo estava errado.

Com G5, o assédio tem ocorrido junto com o assédio do diretor e foi relatado com a mobilização da personagem "pessoas", o que remete aos subordinados, conforme o trecho (26): "algumas pessoas não me aceitaram porque eu era uma analista como eles e eu assumi a área quando a [antiga gerente] saiu, então tinha muita gente que queria o meu lugar". O assédio provém de subordinados da antiga gestão, que almejavam o cargo de gerente, conforme os vocábulos "analista como eles" e "queria o meu lugar". G5 descreveu, no fragmento (27), atitudes de subordinados que levam às classificações de Hirigoyen (2002b): deterioração proposital das condições de trabalho e atentado contra a dignidade, pois parece que tentam induzi-la ao erro e desacreditá-la no trabalho.

(27) [...] as pessoas não assumem responsabilidades... para algumas pessoas eu falava assim: “... porque você esperou chegar o dia pra me falar que não ia fazer?"... ela fica fazendo as coisas para me sacanear... eu tenho que ficar ligadaça porque senão ela pode me queimar. Ela inferniza, ela não trabalha [...].

G8 citou dois casos de assédio ascendente, o primeiro dos quais ocorreu quando a empresa na qual trabalha ainda era pública. No primeiro caso, relatado no trecho (28), G8 indicou a existência de lideranças informais na sua equipe, pois os ex-gerentes, que haviam perdido o cargo e eram seus subordinados agora, continuavam a agir como gerentes com os antigos subordinados, enfraquecendo o poder de sua gestão. G8 informou ter sido vítima de vários comportamentos de assédio desse grupo de subordinados, que podem ser categorizados como deterioração proposital das condições de trabalho.

(28) [...] existiam grupos... eu era gerente e tinham pessoas que tinham sido gerentes, eles agrupavam ali os $\underline{\text { co- }}$ mandados deles... para, tipo, enfraquecer mesmo a liderança. É como se você falasse e batesse na parede e voltasse... existia era uma intenção de que aquilo que você estava programando não ia dar certo... sabotagem... você tinha a informação pela metade.

O segundo caso ocorreu na empresa já privatizada, proveniente da personagem ele, seu subordinado, no cargo de gerente de projetos em que ainda ocupa. O assédio durou o período em que o funcionário ficou sob sua subordinação: um ano e oito meses. Para G8, esse caso de assédio, conforme explicitado nas marcas textuais sublinhadas no trecho (29), foi decorrente da competição pelo cargo gerencial e pode ser classificado como isolamento e recusa de comunicação, atentado contra a dignidade e deterioração proposital das condições de trabalho: "[...] ele se sentiu muito enciumado... achou que deveria ser o gerente... fez boicote feio na equipe. Ele passava o serviço direto para o cliente sem passar pela minha aprovação... eu chamava para reunião e ele não vinha... ele falava mal [de mim]".

Nesta pesquisa, esse assédio foi menos freqüente que o descendente e teve como ponto comum a rejeição da gerente no cargo. A maioria dos casos de assédio pare- 
ceu ter ocorrido porque os subordinados gostariam de ter sido promovidos no lugar da gerente, passando a não legitimá-la no cargo.

\section{Subconjunto do assédio moral horizontal}

$O$ último subconjunto desse percurso semântico, assédio moral horizontal, teve a menor frequêencia nas entrevistas. O primeiro tema, rejeição, surgiu no discurso de G1, no trecho (30): "[...] tem 35 anos de empresa... mestre dos mestres... ensinou para todos os outros gerentes... 'Não, filhinha, você já sabe tudo'... aponto os erros e ele não faz nada... parece que eu que sou incompetente". O assédio acontece desde que assumiu a gerência financeira no lugar do atual gerente da unidade, o qual caracteriza pela metáfora "mestre dos mestres" por saber muito do serviço e ensinar a todos. No entanto, a atitude dele com G1 foi diferente, pois faz questão de não ensiná-la ou, se o faz, ensina de forma complicada, além de tratá-la pejorativamente como "filhinha". Gl informou que precisa do gerente da unidade para resolver questões, mas ele ignora as solicitações dela. Esse assédio leva à categorização do tipo deterioração proposital das condições de trabalho porque induz a vítima ao erro e não lhe transmite informações úteis para realização de tarefas.

O segundo tema deste subconjunto é competência e foi identificado em dois casos de assédio relatados por G2, ocorridos na empresa anterior, onde era assessora do superintendente e coordenadora do programa de Qualidade Total. Para G2, esses casos de assédio ocorreram juntamente com o assédio do superintendente e o da diretora de atendimento, resultando na sua demissão. Segundo G2, esses dois assédios surgiram por causa de sua ascensão profissional e atentaram contra a sua dignidade, uma vez que a ex-secretária do superintendente, trecho (31): "[...] repassava para a esposa detalhes do dia-a-dia... não sei se ela tinha intenção ou não de envenenar... nos bastidores eu achava que ela [...]", e a colega de custos, trecho (32) "[...] se incomodou com a minha ascensão... eu tenho quase certeza que vários comentários maldosos foram feitos, entendeu?", espalharam "comentários maldosos" sobre o relacionamento próximo de G2 com o superintendente.

No último tema deste subconjunto, ameaça ao poder, G2 relatou, no trecho (33): "[...] o programa de qualidade começou a apertar a gestão dela... foi se sentindo pressionada... queria me tirar da reta e era amiga íntima da [esposa do superintendente]... ela foi e agiu nos bastidores contra mim [...]", um caso de assédio horizontal proveniente da diretora de atendimento. Esse assédio foi atribuído por G2 à exposição de falhas da diretora, reveladas pelo programa de qualidade do qual G2 era coordenadora. A gerente subentendeu que a diretora, amiga íntima da esposa do superintendente, passou a fazer insinuações a respeito do relacionamento próximo com superintendente e essa atitude objetivaria a demissão de G2 para que não revelasse as vulnerabilidades da sua gestão, o que leva à categorização atentado contra a dignidade.

G4 informou ser vítima de vários comportamentos de assédio horizontal no cargo de gerente de RH, ocupado há 10 anos. No caso do gerente de Produção, o assédio parece ser mais direto e agressivo, pois os vocábulos sublinhados do trecho (34) levam à classificação violência verbal e física: "[...] gerente [de produção] me mandou a tampa de uma caneta... porque ele quis que eu admitisse um colega dele que não passou nos testes... eu só não apanhei porque um segurança entrou... hoje eu não converso com ele, se ele vem gritar eu saio de perto".

Já no trecho (35): "Eles falam tanto mal de mim... grupinho... então o falatório é geral... umas vinte e poucas pessoas... sofri muito com assédio porque achavam que eu tinha poder por causa da ligação que eu tenho direto com meu chefe", G4 relatou atitudes de um grupinho que inclui gerentes e pessoas da área administrativa que podem ser categorizadas como atentado contra a dignidade.

No fragmento (36), G11 relatou o assédio horizontal de que tem sido vítima, porém não nomeou explicitamente as personagens, mas utilizou vocábulos para identificá-las: "perigosos", "alta administração", "tubarões" e "pessoa de RH". As marcas textuais sublinhadas levam às categorias de assédio deterioração proposital das condições de trabatho e isolamento e recusa de comunicação. A personagem "pessoa de RH" pode ser subentendida como um desses tubarões, já que G11 caracterizou seu relacionamento com esse profissional como "ostensivo" e "embate violento", além de utilizar a hipérbole: "se um dia aparecer morta, ele é o primeiro da lista".

(36) Os perigosos... tentam te sabotar... dá uma distorcida, até você falar que não é bem assim, já foi feito o inferno... quando querem criar embate com ele [presidente], tentam me vender; eu percebi esse jogo... alta administração me usando... você vai criando a turma para você não ficar sozinha no meio dos tubarões. O tubarão isola a área dele... faz tudo com os outros... o mais ostensivo é essa pessoa $\underline{\text { de } \mathrm{RH}}, \ldots$ o embate violento; $\underline{\text { se um dia aparecer morta, ele }}$ é o primeiro da lista [...].

O estudo do percurso semântico do assédio moral buscou evidenciar nas entrevistas casos de assédio que as gerentes foram ou estão sendo vítimas, entendendo cada narrativa 
como uma peça do quebra-cabeça que, como nova peça, evidencia o processo de assédio moral na gerência.

\section{CONSIDERAÇÕES FINAIS}

Com a pesquisa, verificou-se que, dentre os três tipos de assédio definidos por Hirigoyen (2002a, 2002b), o mais indicado pelas gerentes foi o descendente, o que confirma o pressuposto da autora de que esse seria o assédio mais comum nas organizações. Já a categoria deterioração proposital das condições de trabalho foi a mais citada, inferindo-se que os agressores preferiram atitudes que desabonassem a imagem da gerente em relação ao trabalho, o que pode fazer com que ela própria ou outros profissionais passem a duvidar da sua competência profissional.

Analisando os possíveis causadores dos assédios, verificou-se que: 1) o chefe tenta demarcar o espaço na organização por meio de atitudes hostis com a gerente, colocando-a em posição inferior de dominação; 2) um subordinado ou um grupo não aceita a gerente como superior por causa da disputa pelo cargo ou por serem pares hierárquicos, marcando um conflito de poder; 3 ) um indivíduo ou um grupo tenta eliminar ou isolar a gerente, pois ameaça a sua gestão.

A análise dos relatos permitiu perceber, como pano de fundo dos casos de assédio, as relações de poder. Essa proposição remete a Melo $(1984,1995)$, que indica que o poder está presente nas relações sociais e os conflitos são inerentes às relações de poder. Estas permeiam a organização e ficaram presentes em todos os níveis hierárquicos e não somente nas relações de autoridade, o que explica a ocorrência de casos de assédio moral do tipo horizontal e ascendente. Por serem formas de dominação e de controle (Melo, 1995), parecem trazer uma elucidação e uma possibilidade de (re)leitura bastante antiga do que se denomina hoje de assédio moral.

Ao se definir a mulher como objeto de estudo, buscouse também entender como tem ocorrido a sua transição para cargos gerenciais. A maioria dos casos de assédio relatados ocorreu na função gerencial, o que demonstra que grande parte das entrevistadas continua vivenciando o fenômeno, mesmo em cargos de gerência, sendo talvez até mais expostas por estarem em um terreno de domínio masculino, destacadamente ao se constatar que, de 18 casos narrados de assédio descendente, 15 agressores eram homens.

Verificou-se que um fator agravante dos casos de assédio foi a omissão da empresa para cessar os abusos, uma vez que ninguém foi culpado. Muitas organizações têm como prática a não intervenção, sendo complacentes com certos excessos de poder. Algumas até estimulam a competitividade entre os colegas, visando o aumento da eficiência organizacional. $\mathrm{O}$ assédio também pode ser adotado por representantes da empresa para que profissionais peçam demissão, desonerando-a de custos. Por outro lado, as gerentes não denunciaram os casos de assédio, preferiram o silêncio.

Finalmente, por meio desta pesquisa, buscou-se uma contribuição para os estudos administrativos ao se evidenciar como os comportamentos de assédio moral degradam as relações de trabalho, podendo adoecer indivíduos e colocar em risco o emprego. A predominância do assédio moral descendente e de atitudes que desabonassem a gerente em relação ao trabalho pode retratar práticas organizacionais contemporâneas pautadas na competitividade e nas disputas de poder. Ademais, questiona-se até que ponto as gerentes também não adotaram certos comportamentos para ascenderem e permanecerem na gerência, impondo um poder aos colegas e subordinados, que podem reagir com atitudes que também levam ao assédio moral.

Após essa discussão conceitual, acredita-se ser interessante (re)estudar o assédio moral sob o enfoque das relações de poder, possibilitando novas reflexões e um aprofundamento do fenômeno. Entende-se que este trabalho pode ser complementado com a realização de pesquisas que abordem outras perspectivas de análise, tais como as seguintes proposições: investigar o assédio moral entre homens e mulheres gerentes, identificando os pontos convergentes e divergentes; analisar o assédio moral sob o enfoque das relações de gênero; investigar o assédio moral nas diversas hierarquias de uma única organização.

É prudente reconhecer também a limitação da pesquisa, uma vez que somente a gerente foi ouvida. Ela pode ter selecionado os eventos narrados como situações positivas a seu respeito omitindo fatos desagradáveis. Tentouse superar parcialmente tais limitações pela análise do discurso, mas Fiorin (2003, p. 49) lembra que ela não é investigação policial, pois não se pode saber "[...] se o falante revela ou não sua verdadeira visão de mundo, ao enunciar um discurso [...]".

\section{REFERÊNCIAS}

AGUIAR, A. L. S. Assédio moral nas organizações: estudo de caso dos empregados demitidos e em litígio trabalhista no Estado da Bahia. 2003. 188 f. Dissertação (Mestrado em Administração Estratégica) - Universidade Salvador - Unifacs, Salvador, 2003. 
BARRETO, M. M. S. Uma jornada de humilhações. 2000. 266 f. Dissertação (Mestrado em Psicologia Social) - Pontifícia Universidade Católica de São Paulo, São Paulo, 2000.

BARRETO, M. M. S. Assédio moral: o risco invisível no mundo do trabalho. Jornal da rede feminista de saúde, São Paulo, n. 25, p. 12-16, jun. 2002.

COSTA, S. G. da. Assédio sexual: uma versão brasileira. Porto Alegre: Artes e Ofícios, 1995.

DAVEL, E. P. B.; VASCONCELOS, J. G. M. Gerência e autoridade nas empresas brasileiras: uma reflexão histórica e empírica sobre a dimensão paterna nas relações de trabalho. In: MOTTA, F. C. P.; CALDAS, M. P. (Orgs.). Cultura organizacional e cultura brasileira. São Paulo: Atlas, 1997. cap. 5, p. 94-110.

FARIA, A. A. M. Interdiscurso e intradiscurso: da teoria à metodologia. In: MENDES, E. A. de M.; OLIVEIRA, P. M.; BENN-IBLER, V. (Org.). O novo milênio: interfaces lingüísticas e literárias. Belo Horizonte: UFMG/FALE, 2001. p. 31-37.

FARIA, A. A. M.; LINHARES, P. T. F. S. O preço da passagem no discurso de uma empresa de ônibus. Cadernos de Pesquisa, Belo Horizonte, v. 10, p. 32-38, 1993.

FIORIN, J. L. Linguagem e ideologia. São Paulo: Ática, 2003.

FREITAS, M. E. Assédio moral e assédio sexual: faces do poder perverso nas organizações. Revista de Administração de Empresas, v. 41, n. 2, p. 8-19, 2001.

HELOANI, J. R. M. Assédio moral: um ensaio sobre a expropriação da dignidade no trabalho. RAE-eletrônica, v. 3, n. 1, 2004.
HIRIGOYEN, M. F. Assédio moral: a violência perversa no cotidiano. 5. ed. Rio de Janeiro: Bertrand, 2002a.

HIRIGOYEN, M. F. Mal-estar no trabalho: redefinindo o assédio moral. Rio de Janeiro: Bertrand, 2002b.

LEYMANN, H. The content and development of mobbing at work. European Journal of Work and Organizational Psychology, v. 5, n. 2, p. 165-184, 1996.

MAINGUENEAU, D. Termos-chave da análise do discurso. Belo Horizonte: Editora UFMG, 1998.

MARRE, J. L. História de vida e método biográfico. Cadernos de Sociologia, v. 3, n. 3, p. 89-141, 1991

MELO, M. C. O. L. Processos de participação como meios não institucionalizados de regulação de conflitos. Revista de Administração de Empresas, v. 24, n. 4 , p. $11-18,1984$

MELO, M. C. O. L. Estratégia do(s) empregado(s) no quotidiano das relações de trabalho: a construção de processos de auto-regulação. In: DAVEL, E.; VASCONCELLOS, J. (Orgs.). "Recursos" Humanos e subjetividade. Petrópolis: Vozes, 1995. p. 168-183.

RAMÍREZ, L. G. Reflexões sobre o assédio moral no trabalho. Disponível em: $<$ http://www.abrat.adv.br/textos/artigos/2002/artigo-025.html>. Acessado em 04 jul. 2004.

RODRIGUES, R. L. de F. A temática ambiental no discurso da Companhia Vale do Rio Doce: jornal Vale Notícias - Minas. 2004. 144 f. Dissertação (Mestrado em Lingüística) - Universidade Federal de Minas Gerais, Belo Horizonte, 2004.

\title{
Artigo recebido em 05.09.2005. Aprovado em 02.03.2006.
}

\section{Alessandra Morgado Horta Corrêa \\ Mestre em Administração pela UFMG.}

Interesses de pesquisa nas áreas de assédio moral nas organizações, discursos, representa-

ções sociais e culturas.

E-mail: alessandramorgado@hotmail.com

Endereço: 500 East 77th St \#838 - New York, NY, 10162.

\author{
Alexandre de Pádua Carrieri \\ Doutor em Administração pela UFMG. Professor e pesquisador do Centro de Pós-Graduação \\ e Pesquisa em Administração da UFMG. \\ Interesses de pesquisa nas áreas de estudos organizacionais e simbolismo, estratégias, rela- \\ ções de poder e de trabalho, comportamento e mudança organizacional. \\ E-mail: alexandre@cepead.face.ufmg.br \\ Endereço: Rua Curitiba, 832, $11^{\circ}$ andar, Centro, Belo Horizonte, Minas Gerais - MG, \\ 30170-120.
}

